\title{
Triciribine Phosphate
}

National Cancer Institute

\section{Source}

National Cancer Institute. Triciribine Phosphate. NCI Thesaurus. Code C1262.

The phosphate salt of the synthetic, cell-permeable tricyclic nucleoside triciribine with potential antineoplastic activity. Triciribine inhibits the phosphorylation, activation, and signalling of Akt-1, -2 , and -3 , which may result in the inhibition of Akt-expressing tumor cell proliferation. Akts are anti-apoptotic serine/threonine-specific protein kinases that phosphorylate and inactivate components of the apoptotic machinery, including BclxL/BCl-2-associated death promoter (BAD) and caspase 9. 